\title{
Rocuronium Use in Anaesthetics Protocol in Canine Patients with Orthopedic Disease
}

\author{
Cristian Paul POPOVICI ${ }^{*}$, Mircea MIRCEAN ${ }^{1}$, Iuliu SCURTU ${ }^{1}$, Ciprian OBER ${ }^{2}$, Cosmin PESTEAN, Bogdan \\ SEVASTRE $^{3}$, Liviu OANA ${ }^{2}$ \\ ${ }^{1}$ Faculty of Veterinary Medicine, Department of Internal Medicine, University of Agricultural Sciences \\ and Veterinarian Medicine, Cluj-Napoca, 3-5, Mănăștur Street, 400372, Romania. \\ ${ }^{2}$ Faculty of Veterinary Medicine, Department of Anaesthesiology and Surgical Techniques, University of \\ Agricultural Sciences and Veterinarian Medicine, Cluj-Napoca, 3-5, Mănăștur Street, 400372, Romania. \\ ${ }^{3}$ Faculty of Veterinary Medicine, Department of Pathophysiology, University of Agricultural Sciences \\ and Veterinarian Medicine, Cluj-Napoca, 3-5, Mănăștur Street, 400372, Romania. \\ *Corresponding author e-mail: popovici_vet@yahoo.com
}

Bulletin UASVM Veterinary Medicine 71(2) / 2014,

Print ISSN 1843-5270; Electronic ISSN 1843-5378

DOI:10.15835/buasvmcn-vm: 10796

\begin{abstract}
In modern veterinary medicine, like in human medicine all major surgery procedures must be performed under balanced anaesthesia. This protocol contained substances that insure: neurovegetativ protection, analgesia, miorelaxation, hypnosis. Rocuronium represent a nondepolarizing agent, intermediate acting ( 60-120 seconds), with relative long effects ( 40-90 minutes), and with the posibility of effect reversal ( agents-Sugammadex). The aim of this study was monitorization of clinical, haematological and biochemical parameters perioperative in dogs scheduled for orthopedic procedures. This study was performed on five canine patients (different breed, with age between 4 months to 11 years), scheduled for femoral had resection procedure. In this dogs balanced anaesthesia was performed: induction with propofol to effect, maintained with sevoflurane $2.5 \%$; analgesic component: fentanyl $3 \mu \mathrm{g} / \mathrm{kg}$ b.w.-bolus followed by CRI $5 \mu \mathrm{g} / \mathrm{kg}$ b.w. $/ \mathrm{min}$, the neuromuscular blocking agent was represented by rocuronium $0.4 \mathrm{mg} / \mathrm{kg}$ b.w. Haematological analysis were performed with Abacus Junior Vet 3 diff analyzer, biochemical parameters with UV-VIS Screen Master Touch Hospitex Diagnostic spectrophotometer, and electrolytes with GEM Premier 2000 analyzer. The majority of biochemical and mineral parameters suffered only small changes, without statistical importance. After the surgery we determined only a slight reduction of erythrocyte number, haemoglobin and PCV, a mild increase of $\gamma$-globulin. Regarding the clinical parameters only internal temperatures was modified. We recommend the use of rocuronium in orthopedic procedures for the advantages offered in the surgical act (profound miorelaxation) without any major biochemical, haematological, electrolytes alteration.
\end{abstract}

Keywords: canine, orthopedic, rocuronium, general anaesthesia

\section{INTRODUCTION}

In modern veterinary medicine, like in human medicine all major surgery procedures must be performed under balanced anaesthesia. That is more important in pacients with orthopedic problems (Chohan, 2011). This protocol contained substances that insure: neurovegetativ protection, analgesia, miorelaxation and hypnosis.

The muscle relaxants ensure a better muscle relaxation and from this big category of drugs
NMBA is prefered (Chohan, 2010). Rocuronium is a nondepolarizing blocking agent (NMBA), intermediate acting (60-120 seconds), with relative long effects (40-90 minutes), and with the possibility of effect reversal (agents-Sugammadex) (Raghavendra, 2002). For this moment there are limited studies in veterinary medicine regarding the use of this agent in balanced anaesthesia (Stevens, 1997; Brauer, 2011; Duke-Navakoski, 2012), but the safety is proven by studies from 
Tab. 1. Epidemiological structure of the cases

\begin{tabular}{|c|c|c|c|c|c|}
\hline $\begin{array}{l}\text { Pacient } \\
\text { number }\end{array}$ & Breed & Age & Sex & $\begin{array}{c}\text { Chirurgical } \\
\text { diagnosis }\end{array}$ & $\begin{array}{c}\text { Intervention } \\
\text { time }\end{array}$ \\
\hline 1 & Caniche & 11years & $\mathrm{F}$ & $\begin{array}{c}\text { Recurrence } \\
\text { of coxofe- } \\
\text { moral luxation }\end{array}$ & 64 minutes \\
\hline 2 & Cocker & 2 years & M & $\begin{array}{l}\text { Chronic } \\
\text { femoral head } \\
\text { fracture }\end{array}$ & 60 minutes \\
\hline 3 & $\begin{array}{l}\text { Bichon } \\
\text { bolognez }\end{array}$ & 9 months & M & $\begin{array}{l}\text { Leg-Perthess } \\
\text { disease }\end{array}$ & 45 minutes \\
\hline 4 & Tosa-Inu & 14 months & M & $\begin{array}{c}\text { Chronic Salter- } \\
\text { Harris type } 2 \\
\text { fracture }\end{array}$ & 31 mnutes \\
\hline 5 & $\begin{array}{l}\text { Yorkshire } \\
\text { Terrier }\end{array}$ & 4 months & $\mathrm{F}$ & $\begin{array}{l}\text { Leg-Perthess } \\
\text { disease }\end{array}$ & 52 minutes \\
\hline
\end{tabular}

human medicine (Khalil, 1994; Mirakhur, 1994; Robertson, 2005; Craig, 2009)

\section{MATERIALS AND METHODS}

This study was performed on five canine patients (different breed, with ages between 4 months to 11 years), scheduled for femoral had resection procedure (the structure of this group is present in Tab. 1). In all cases we used a balanced anaesthesia protocol: induction - propofol (Propofol 1\%, 20 ml," Fresenius”, Kabi Deutschland $\mathrm{GmbH}$, Germany) to effect, maintenance sevoflurane 2, 5\% (Sevofluran $250 \mathrm{ml}$, Abbott Laboratories Ltd, U. K.); - analgesia fentanyl $3 \mu \mathrm{g} /$ kg b.w.- bolus (Fentanyl-Richter $5 \mathrm{ml}, 50 \mu \mathrm{g} / \mathrm{ml}$ ) followed by CRI $5 \mu \mathrm{g} / \mathrm{kg}$ b.w./min (Braun Perfusor FM- infusion pump), miorelaxation - rocuronium $0,4 \mathrm{mg} / \mathrm{kg}$ b.w. (Rocuronium Kabi $10 \mathrm{mg} / \mathrm{ml}$ $10 \mathrm{ml}$,S.C.Fresenius Kabi Romania) bolus.

The patients were endotracheal intubated and mechanical ventilation was started (IPPV) $15 \mathrm{mbar}, 15 \mathrm{ml} / \mathrm{kg}$ b.w., 15 breaths/min (Dräger Cato VT 20 anaesthesia machine). Ventilator parameters were adjusted in conformity with ETCO $_{2}$ values during the duration of surgical procedures.

The blood sample was collected in to different time : 1-before the beginning of general anaesthesia and 2-at 120 minute.

Blood hematology was investigated with Abacus Junior Vet, automatic analyzer Diatron Messtechnik, Budapest, Hungary.
Biochemical parameters were investigated with Spectrophotometer Screen Master Touch (Hospitex Diagnosis Italy) using following biochemical methods:

- kinetic-enzymatic assay in u.v. light's at $\lambda 340 \mathrm{~nm}$ ALAT, ASAT, GGT, PAL, LDH and Urea;

- kinetic-colorimetric method, fixed time, in visible spectrum (v.i.s) at $\lambda 405 \mathrm{~nm}$ Creatinine;

- end-point method, colorimetric in vi.is. at: $\lambda=480$ Glucoses, $\lambda=548$ Total protein $=600$ Albumin, $\lambda=$ $540 \mathrm{~nm}$ Calcium;

- turbidimetrical in v.i.s. at $\lambda=405 \gamma$-globulins;

- enzymatic fixed time method in u.v. at $\lambda=340 \mathrm{~nm}$ Phosphorus.

Materials: intravenous catheter Vasofix $® S a-$ fety 22 G $(0,9 X 25)$ (producer Braun); blood collectors Microvette ${ }^{\circledR}$ MicroTube 1,3 ml EDTA; "Blood sample for Blood Gas with cone cap" heparinate syringe $2 \mathrm{ml}$ (producer Instrumentation Laboratory); Urea; Creatinine; ALAT; ASAT; GGT; PAL; LDH; Calcium; Total Protein; Albumin; Globulin diagnosis kits (producer Hospitex Diagnostic, Firenze, Italia); Phosphorus diagnosis kits (producer by Ameda Labordiagnostik ,Granz, Austria)

Statistics - the data were expressed as the mean and standard error of the mean (SEM). Pared sample T Student test was used to assess the differences between the two moments investigated. Statistical significance was at $p<0.05$ (95\% confidence interval). Statistical values 
were obtained using GraphPad Prism version 5.0 for Windows, GraphPad Software, San Diego California USA.

\section{RESULTS AND DISCUSSION}

The results are presented in the following tables, because of the individuals variations and the multitudes of the parameters we chose to show only the mean values and standard error of the mean (S.E.M.) so the results to be more easy to follow.

In veterinary medicine there are no study, from our knowledge, to assess the degree of post operative anemia, but in human medicine, two major studies conclude that in $90 \%$ of orthopedic surgery anemia is present postoperative (Kulier, 2001; Dunne, 2002). After the surgery in our cases we noticed a mild anemia.

The others red blood cell parameters remained in normal limits.

The plates count was and remained in normal limits after the general anaesthesia and surgery.

We detected a reduction of white blood cell at 120 minute after the surgery, that remained in normal limit, most probably caused by migration of this cells from blood stream to surgery site.

The glucose level is much higher before the surgery, probably caused by the pain, this finding

Tab. 2. The influence of anesthesia on the values of the red blood cells (RBCs), hemoglobin (HGB) and hematocrit (HCT) (mean \pm S.E.M).

\begin{tabular}{cccc}
\hline & RBC 10 ${ }^{12} / 1$ & HGB g/l & HCT \% \\
\hline Time 1 & $6.84 \pm 0.22$ & $158.00 \pm 2.31$ & $46.90 \pm 0.55$ \\
Time 2 & $5.23 \pm 0.18^{*}$ & $116.00 \pm 0.95^{*}$ & $35.30 \pm 0.49^{*}$ \\
\hline
\end{tabular}

Note: Normal values: RBC 5.5-8.5 10\%/ $\mu \mathrm{l}, \mathrm{Hb} 120-180 \mathrm{~g} / \mathrm{l}, \mathrm{Ht}$ 37-55 \% (Merk Veterinary Manual)

$*=\mathrm{p}<0.05$ as compared to Group 1

Tab. 3. The influence of anesthesia on the values of mean corpuscular volume (MCV), mean corpuscular hemoglobin $(\mathrm{MCH})$, mean corpuscular hemoglobin concentration (MCHC) and red blood cells distribution width (RDW) (mean \pm S.E.M)

\begin{tabular}{ccccc}
\hline & MCV fl & MCH pg & MCHC g/l & RDWs fl \\
\hline Time 1 & $69.00 \pm 0.39$ & $23.00 \pm 0.20$ & $336.80 \pm 0.66$ & $43.46 \pm 0.31$ \\
Time 2 & $67.20 \pm 0.33$ & $22.00 \pm 0.20$ & $326.60 \pm 0.68$ & $43.58 \pm 0.31$ \\
\hline
\end{tabular}

Note: Normal values: MCV 60-72 fl MCH 19.5-24.5 pg MCHC 310-340 g/dl (Merk Veterinary Manual)

Tab. 4. The influence of anesthesia on the values of total platelet count (PLT), platelet hematocrit (PCT), mean platelet volume (MPV), platelet distribution width (PDW) (mean \pm S.E.M.)

\begin{tabular}{ccccc}
\hline & PLT $10^{3} \mathrm{cells} / \mu \mathrm{l}$ & PCT \% & MPV fl & PDWs fl \\
\hline Time 1 & $241.00 \pm 1.59$ & $0.25 \pm 0.05$ & $10.00 \pm 0.10$ & $15.36 \pm 0.23$ \\
Time 2 & $266.00 \pm 1.98$ & $0.27 \pm 0.06$ & $10.00 \pm 0.20$ & $15.46 \pm 0.27$ \\
\hline
\end{tabular}

Note: Normal values: PLT 200-500 10³ cells/ $\mu$ (Merk Veterinary Manual)

Tab. 5. The influence of anesthesia on the WBC count and differential count (mean \pm S.E.M.)

\begin{tabular}{ccccc}
\hline & WBC $\mathbf{1 0}^{9} / \mathbf{l}$ & LYM 10 $^{9} / \mathbf{l}$ & MID 10 $^{9} / \mathbf{l}$ & GRA 10 $^{9} / \mathbf{l}$ \\
\hline Time 1 & $13.26 \pm 0.46$ & $2.00 \pm 0.40$ & $0.83 \pm 0.13$ & $10.50 \pm 0.31$ \\
Time 2 & $7.02 \pm 0.41$ & $0.90 \pm 0.10$ & $0.38 \pm 0.10$ & $5.71 \pm 0.40$ \\
\hline
\end{tabular}

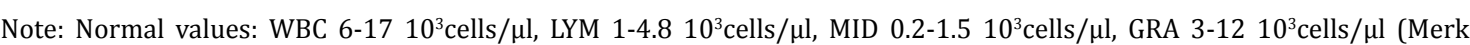
Veterinary Manual) 
Tab. 6. .The influence of anesthesia on the glucoses, ureea and creatinine (mean \pm S.E.M.)

\begin{tabular}{cccc}
\hline & $\begin{array}{c}\text { Glucosis mg/ } \\
\text { dl }\end{array}$ & uree & creatinine \\
\hline Time 1 & $235.58 \pm 1.96$ & $29.8 \pm 0.53$ & $0.77 \pm 0.08$ \\
Time 2 & $160.26 \pm 1.59$ & $35.1 \pm 0.4$ & $0.79 \pm 0.08$ \\
\hline
\end{tabular}

Note: Normal values: 63-100 mg/dl, urea 24-54 mg/dl, creatinine 0.48-1.54 mg/dl (Internal Medicine Pathology Laboratory FMV Cluj-Napoca refence values)

Tab. 7. The influence of anesthesia on the calcium, inorganic phosphorus, natrium and potassium (mean \pm S.E.M.)

\begin{tabular}{ccccc}
\hline & $\begin{array}{c}\text { Calcium } \\
\mathrm{mg} / \mathrm{dl}\end{array}$ & $\begin{array}{c}\text { Phosphorus } \\
\mathrm{mg} / \mathrm{dl}\end{array}$ & $\begin{array}{c}\text { Natrium m } \\
\mathrm{Eq} / \mathrm{L}\end{array}$ & Potassium mEq/L \\
\hline Time 1 & $10.98 \pm 0.20$ & $5.39 \pm 0.13$ & $141.4 \pm 5.41$ & $4.08 \pm 0.65$ \\
Time 2 & $11.61 \pm 0.36$ & $5.55 \pm 0.13$ & $141 \pm 4.3$ & $3.96 \pm 0.35$ \\
\hline
\end{tabular}

Note: Normal values: calcium 10.48-11.52 mg/dl, phosphorus 2.47-5.57 mg/dl , natrium 135-155mEq/L , potassium 3,5-5,5 $\mathrm{mEq} / \mathrm{L}$ (Internal Medicine Pathology Laboratory FMV Cluj-Napoca refence values).

Tab. 8. The influence of anesthesia on the ALAT, ASAT, LDH, GGT, PAL(mean \pm S.E.M.)

\begin{tabular}{cccccc}
\hline & ALAT U/L & ASAT U/L & LDH U/L & GGT U/L & PAL U/L \\
\hline Time1 & $85.58 \pm 1.85$ & $113.7 \pm 2.79$ & $163.8 \pm 2.42$ & $11.54 \pm 0.95$ & $275.8 \pm 2.34$ \\
Time2 & $51.92 \pm 1.07$ & $28.63 \pm 0.37$ & $153.6 \pm 1.39$ & $8.06 \pm 0.32$ & $232.2 \pm 1.98$ \\
\hline
\end{tabular}

Note: Normal values: ALAT under 40U/L, ASAT under 30 U/L, LDH under 200 U/L, GGT under 10 U/L, PAL 30-140 U/L (Internal Medicine Pathology Laboratory FMV Cluj-Napoca refence values)

Tab. 9. The influence of anesthesia on the Total Protein, Albumin and $\gamma$-Globulins (mean \pm S.E.M.)

\begin{tabular}{cccc}
\hline & Total protein $\mathbf{g} / \mathbf{d l}$ & Albumin $\mathbf{g} / \mathbf{d l}$ & $\gamma$-globulin $\mathrm{g} / \mathrm{dl}$ \\
\hline Time1 & $5.42 \pm 0.21$ & $2.27 \pm 0.08$ & $0.86 \pm 0.08$ \\
Time2 & $5.92 \pm 0.28$ & $2.4 \pm 0.12$ & $1.13 \pm 0.08^{*}$ \\
\hline
\end{tabular}

\footnotetext{
Normal values : Total Protein : 4-6,4 g/dl, Albumin :1,7-3,14 g/dl, $\gamma$-Globulin 0,3-1,34 g/dl (Internal Medicine Pathology Laboratory FMV Cluj-Napoca refence values)

$*^{*}=\mathrm{p}<0.05$ as compared to time 1
}

is different from findings of Selmi 2009 (in that study the glucose level and cortisol concentration were significantly higher within 1 hour after the surgery). Normal level of ureea and creatinine show that the renal filtration remains normal and the anesthetic protocol will have a minimal impact on renal perfusion.

After the surgery the calcium and phosphorus level are increased, fact that is in conformity with the study made by Speed 1931 in human medicine ( cited by Hardy 1993) after orthopedic procedures. To our knowledge no such studies exist in veterinary medicine.
Only one mild decree is observed in potassium level, but remains in normal limit.

Alanin aminotransferases is located in hepatocytes citosol (for diagnosis of hepatocelular disease the values of this enzyme must be higher than four times the upper limit), but also is erythrocytes and striated muscle cell. Also aspartate aminotransferases is located in hepatocytes (more exactly in mitochondria), but can be found in muscle cells and in red blood cells (Alvarez a, 2009). Due to increased values found before the anesthesia and operation we concluded that these modifications are determined by the 
muscular trauma. The Cholestatic liver enzyme is increased, but the higher level of alkaline Phosphatasis then $\gamma$-Glutamyl transpeptidases reflect the bone isoenzyme (that can be elevated is younger or older dogs) (Alvarez b, 2009).

After the surgery due to local inflammation this values can be increased because of catabolic state seen after the injury (Hardy, 1993).

\section{CONCLUSIONS}

After surgery, with balanced anesthesia we found only slight changes in RBC, Hct, Hgb considered normal. The white blood cell count remained in normal limits.

After the surgery glucose level is lower than before surgery ( a major differences from another protocols)

Total protein, albumin, $\gamma$-globulin increase reflects catabolic state after the surgery, but the normal values of ureea and creatinine reflects that the level of renal perfusion remains optimal.

The increase in ALAT, ASAT level is determined by muscle injury and the increase of PAL is determined by bone injury, the anesthetic protocol don't affect the values of these enzymes.

Natrium and Potassium levels remains in normal limits.

\section{RECOMMENDATION}

We recommend the use of Rocuronium in orthopedic procedures for the advantages offered in the surgical act (profound myorelaxation) without any major biochemical, hematological, electrolytes alteration.

\section{REFERENCES}

1. Amadeep SC (2010). Anesthetic Considerations in Orthopedic Patients with or without trauma. Top Companion Anim Med. 25(2):107-119.

2. Boom A, Van Egmond J , Hope F, Van de Pol F (2003). Rapid reversal of rocuronium-induced neuromuscular blockade by Org 25969 is independent of renal function, Anesthesiology 99:A1158

3. Bowmann WC (2006). Neuromuscular block. Br. J. Pharmacol january, 147:277-286

4. Brauer C, Kastner SB, Schenk HC, Tunsmeyer J, Tipold A (2011). Electroencephalographic recording in dogs: Prevention of muscle artifacts and evaluation of two activation techniques in healthy individuals. Res. Vet. Sci. 90:306-311.

5. Craig RG, Hunter JM (2009). Neuromuscular blocking drugs and their antagonists in patients with organ disease, Anaesthesia, 64(1):55-65
6. Duke-Navakoski T, Ambros B, Auckland CD, Harding JC (2012). The effects of succinylcholine or low-dose rocuronium to aid endotracheal intubation of adult sows. Can. J. Vet. Res., 76: 57-61

7. Dunne JR, Malone D, Tracy JK, Gannon C, Napolitano LM (2002). Perioperative anemia: an independent risk factor for infection, mortality, and resource utilization in surgery, J Surg Res. 102(2):237-44.

8. Hardy JRW, Conlan D, Gregg PJ (1993). Serum ionised calcium and its relationship to parathyroid hormone after tibial fracture, The journal of bone and joint surgery, 75:645-649

9. Khalil M, D'Honneur G, Duvaldestin P, Slavov V, (1994). Pharmacokinetics and pharmacodynamics of rocuronium in pacients with cirrhosis. Anesthesiology. 80:1241-1247.

10. Kulier A, Gombotz H. (2001). Perioperative anemia. Anaesthesist. 50(2):73-86.

11. Lucia Alvarez, Whittermore JC a (2009). Liver enzyme elevation in dogs: Physiology and Pathophysiology. Compendium: Continuing Education for Veterinarians, p. 408-414.

12. Lucia Alvarez, Whittermore JC b (2009). Liver enzyme elevation in dogs: Diagnostic Approach. Compendium: Continuing Education for Veterinarians, p. 416-425

13. Martin-Florens M. (2012). The sensitivity of sheep to vecuronium: an example of limitation of extrapolation. Can.J.Anesth, 59: 722-723

14. Martin-Florens M., Pare MD, Adams W, Campoy L, Gleed RD. (2012). Observations of the potency and duration of vecuronium in isoflurane-anesthetized horses. Veterinary Anaesthesia and Analgesia, 39: 385-389

15. Mirakhur RK (1994). Safety aspects of non-depolarizing neuromuscular blocking agents with special reference to rocuronium bromide. European Journal of Anaesthesiology Supplement, 9: 133-140.

16. Robertson EN, Driessen JJ, Booij LH. (2005). Pharmacokinetics and pharmacodinamics of rocuronium in patients with and without renal failure. European Journal of Anaesthesia, 22: 4-10

17. Sanes JR, Lichtmann JW. (2001). Induction, assembly, maturation and maintenace of postsynaptic apparatus. Nature Reviews. Neuroscience, 2: 791-805

18. Schoffmann G, Vettorato E, Burke JG, Gibson AJN, Clutton ER (2012). The effects of age, isoflurane and sevoflurane on atracurium in lambs. Veterinary Anaesthesia and Analgesia, 39: 256-265

19. Stevens JB, Hecker RB, Talbot JC, Walker SC. (1997). The haemodynamic effects of rocuronium and vecuronium are different under balanced anaesthesia. Acta Anasthesiol. Scand., 41: 502-505

20. Thandia Raghavendra (2002). Neuromuscular blocking drugs: Discovery and development, J.R.Soc. Med, 95 (7): 363-367

21. Wang X., Engish KL, Printer MJ, Cope TC, Rich MM (2004). Decreased synaptic activity shifts the calcium dependence of release at mammalian neuromuscular junction in vivo. The Journal of Neuroscience, 24: 10687- 10692. 